БЕСТУГИН А. Р., КРАСЮК В. Н., РЫЖИКОВ М. Б.

\title{
НАГРЕВОСТОЙКАЯ МИКРОПОЛОСКОВАЯ АНТЕННАЯ РЕШЕТКА ДЛЯ ГИПЕРЗВУКОВЫХ ЛЕТАТЕЛЬНЫХ АППАРАТОВ С МАЛОЙ РАДИОЗАМЕТНОСТЬЮ
}

\author{
Санкт-Петербургский государственный университет аэрокосмического приборостроения, \\ Россия, Санкт-Петербург, 190000, ул. Большая Морская, 67
}

\begin{abstract}
Аннотация. Предложена техническая реализация микрополосковой антенной решетки в сегментированном исполнении. Показано, что за счет использования нагревостойких материалов антенная решетка имеет стабильные параметры излучения при высоких температурах и может быть использована для радиотехнических систем гиперзвуковых летательных аппаратов. Представлены результаты исследования, демонстрирующие значительное уменьшение эффективной площади рассеяния такой антенны по сравнению с эквивалентной плоской антенной решеткой
\end{abstract}

Ключевые слова: микрополосковая антенна; антенная решетка; гиперзвуковой летательный аппарат; теплозащитное покрытие; нагревостойкий диэлектрик; тугоплавкий металл; эффективная площадь рассеяния; радиолокационная станция; диаграмма направленности антенны

Создание эффективной многоцелевой авиационно-космической системы требует разработки многоразовых гиперзвуковых самолетов и ракет, имеющих малые габариты и вес. Задача минимизации массогабаритных параметров гиперзвукового летательного аппарата (ГЛА) без потери эффективности работы его радиотехнических систем требует использования антенн малого веса и размеров по отношению к длине волны излучения. Кроме того, эти антенны должны сохранять работоспособность в условиях интенсивного нагрева до высоких температур [1].

Современные ГЛА должны не только летать с гиперзвуковой скоростью по баллистической траектории, но и произвольно изменять направление движения. Полет по сложной траектории способствует возможности преодоления систем противоракетной обороны, если приняты соответствующие меры по снижению радиозаметности. Наличие радиопрозрачных окон приводит к сильному отражению радиолокационных сигналов от антенн, которое может значительно снизить эффективность мер, принятых для снижения заметности ЛА в целом [2]. Все это делает актуальной задачу создания бортовых нагревостойких антенн с малой эффективной площадью рассеяния (ЭПР).

Микрополосковые антенны (МПА) отличаются простотой исполнения, малыми габаритами и весом и их использование в качестве бортовых антенн ГЛА представляет значительный интерес. Например МПА с кольцевой формой излучателя использованы для передачи телеметрической информации на американской межконтинентальной баллистической ракете Minuteman I [3], развивающей скорость до $7 \mathrm{M}$, где М число Маха. МПА с прямоугольной формой излучателя и рабочей частотой 15 ГГц применены для передачи данных многоразово- 